\title{
ANALISIS FAKTOR-FAKTOR YANG MEMPENGARUHI KOMPETENSI DOSEN PADA POLITEKNIK LP3I MEDAN
}

\author{
Trias Ayuning \\ Program Studi Akuntansi, Politeknik LP3I Medan \\ Mayang Murni \\ Program Studi Akuntansi, Politeknik LP3I Medan
}

*Corresponding author: E-mail: Triasayuning22@gmail.com, Mayang.ashari@gmail.com

\begin{abstract}
Abstrak
Berdasarkan data Pusat Data dan Informasi DIKTI, jumlah dosen yang memiliki gelar strata-1 sebanyak 21.872 dari total dosen $2016 / 2017$ sebanyak 237.837. Syarat mustahak yang untuk menjadi seorang pengajar pada program studi di perguruan tinggi di Indonesia adalah memiliki dan menempuh pendidikan hingga strata-2 ataupun stara-3. Penelitian ini bertujuan untuk mengindetifikasi faktor apa saja yang mempengaruhi kompetensi dosen dengan menggunakan uji t dan uji f. Dalam penelitian ini mengemukakan beberapa faktor yaitu kualifikasi akademik, pengalaman mengajar dan motivasi dosen. Berdasarkan hasil penelitian ini motivasi dosen dalam mengajar memiliki pengaruh yang signifikan terhadap kompetensi dosen secara parsial dengan nilai signifikan 0,00 yang lebih kecil dari $\alpha=0,05$, dan secara simultan kualifikasi akademik,pengalaman mengajar dan motivasi memiliki pengaruh yang signifikan terhadap kompetensi dosen dengan nilai signifikansi 0,00 lebih kecil dari $\alpha=0,05$.
\end{abstract}

Kata Kunci : Kompetensi Dosen, Kualifikasi Akademik, Pengalaman, Motivasi dosen

\begin{abstract}
Based on data Center and Information DIKTI, the number of lecturers who have a degree-1 as many as 21,872 of the total lecturer 2016/2017 as many as 237,837. The impossible requirement to be a lecturer in a study program at a college in Indonesia is to have and to be educated up to strata-2 or stara-3. This study aims to identify any factors that affect lecturer competence by using $t$ test and $f$ test. In this research put forward several factors that are academic qualification, teaching experience and motivation of lecturer. Pursuant to result of this research motivation of lecturer in teaching have significant influence to lecturer competence partially with significant value 0,00 smaller than $\alpha=0,05$, and simultaneously academic qualification, teaching experience and motivation have significant influence to lecturer competence with a significance value of 0.00 is smaller than $\alpha=0.05$.
\end{abstract}

Keywords: lecturers competence, academic qualification, experience, motivation of lecturer. 


\section{PENDAHULUAN}

Menteri Riset, Teknologi, dan Pendidikan Tinggi (Menristekdikti) yaitu Muhammad Nasir mengatakan bahwa kualitas dosen menentukan mutu pendidikan tinggi. Salah satu upaya yang dilakukan adalah menggejot kualitas dosen perguruan tinggi hingga ke level strata-2 dan strata-3. Berdasarkan data Pusat Data dan Informasi DIKTI, jumlah dosen yang memiliki gelar strata-1 sebanyak 21.872 dari total dosen 2016/2017 sebanyak 237.837(Surabaya.bisnis.com). Syarat mustahak yang untuk menjadi seorang pengajar pada program studi di perguruan tinggi di Indonesia adalah memiliki dan menempuh pendidikan hingga strata-2 ataupun stara-3. (Bisnis Indonesia, $25 \mathrm{Mei}$ 2017)

Berdasarkan penelitian yang telah dilakukan oleh Nurwati (2000) dengan judul "Faktor-Faktor Yang Berhubungan dengan Kompensi mengajar Dosen mata Kuliah Keahlian pada Akademi Perawat Swasta di Kota Bandung" menghasilkan bahwa faktor-faktor yang mempengaruhi kompetensi dosen adalah latar pendidikan yang didikung oleh akta mengajar, beban mengajar serta umur. Perbedaan penelitian yang akan dilakukan dengan penelitian sebelumnya yaitu dari aspek lokasi dan faktor-faktor yang akan di analisis.

Politeknik LP3I Medan merupakan salah satu perguruan tinggi swasta yang menerapkan program vokasi. Program vokasi bertujuan untuk mempersiapkan tenaga yang dapat menetapkan keahlian dan ketrampilan ,siap kerja dan bersaing secar global. Berdasarkan penjelasan diatas maka dalam penelitian ini disimpulkan judul "Analisis Faktor-faktor Yang Mempengaruhi Kompetensi Dosen Akuntansi pada Politeknik LP3I Medan"

Rumusan masalah dalam penelitin ini adalah apakah Kualifikasi Akademik, Pengalaman mengajar dan Motivasi Dosen berpengaruh terhadap kompetensi dosen akuntansi secara parsial dan secara simultan?

Batasan masalah yang ditentukan dalam penelitian ini adalah kompetensi dosen berdasarkan Undang-undang Republik Indonesia Nomor 14 tahun 2005 tentang guru dan dosen. Kompetensi yang harus dipenuhi dalam sertifikasi meliputi empat hal yaitu, Kompetensi pedagogik, kompetensi sosial, kompetensi profesional dan kompetensi kepribadian yang tertuang dalam satu angket mengenai kompetensi. Faktor yang diamati dalam penelitian ini adalah kualifikasi akademik, pengalaman mengajar dan motivasi dosen.

Tujuan penelitian yang diambil berdasarkan perumusalan masalah diatas adalah untuk mengetahui apakah Kualifikasi Akademik, Pengalaman mengajar dan Motivasi berpengaruh terhadap kompetensi dosen akuntansi secara parsial dan secara simultan.

\section{Pengertian Kompetensi Dosen}

Pada dasarnya kompetensi tidak dapat dilepaskan dari konsep dan tugas guru atau dosen. Kompetensi yang dimiliki seorang pengajar akan terlihat dari perilakunya pada saat melakukan pekerjaannya. Menurut Kamus Besar Bahasa Indonesia (KBBI), " Kompetensi adalah kecakapan, mengetahui, berwenang, dan berkuasa memutuskan atau menetukan atas sesuatu".

Sedangkan pengertian kompetensi menurut Undang-undang No.14 pasal 1 ayat 10 Tahun 2003, "Kompetensi adalah kemampuan kerja setiap individu yang mencakup aspek pengetahuan, keterampilan, dan sikap kerja yang sesuai dengan standart yang ditetapkan".

Menurut UU tentang Guru dan Dosen pasal 1 ayat 1 tahun 2005, " Dosen adalah pendidik professional dan ilmuwan dengan tugas utama mentransformasikan, mengembangkan dan menyebarluaskan ilmu pengetahuan, teknologi dan seni 
melalui pendidikan, penelitian dan pengabdian masyarakat".

Merujuk pada beberapa pendapat yang dijabarkan diatas ,maka dapat disimpulkan Kompetensi dosen adalah kemampuan kerja dalam menjalankan pekerjaannya sebagai seorang pendidik professional dalam menyebarluaskan ilmu pengetahuan sesuai dengan pengetahuan yang dimilikinya.

Kompetensi dosen sebagaimana yang dimaksud dalam Pasal 10 UndangUndang Republik Indonesia nomor 14 tahun 2005 meliputi kompetensi pedagogik, kompetensi kepribadian, kompetensi sosial, dan kompetensi profesional yang diperoleh melalui pendidikan profesi. Keempat kompetenstersebut dapat dideskripsikan sebagai berikut :

1. Kompetensi pedagogik merupakan kemampuan guru dalam mengelola pembelajaran, sekurang-kurangnya meliputi : (a) Pemahaman wawasan atau landasan kependidikan, (b) Pemahaman terhadap peserta didik (c) Pengembangan kurikulum/silabus, (d) Perancangan pembelajaran (e) pelaksanaan pembelajaran yang mendidik dan dialogis, (f) Pemanfaatan teknologi pembelajaran, (g) Evaluasi proses dan hasil belajar dan,(h) Pengembangan peserta didik untuk mengaktualisasikan berbagai potensi yang dimilikinya.

2. Kompetensi kepribadian sekurangkurangnya mencakup : (a) Berakhlak mulia, (b) Arif dan bijaksan, (c) Mantap, (d) Berwibawa, (e) Stabil, (f) Dewasa, (g) Jujur, (h) Mampu menjadi teladan bagi peserta didik dan masyarakat, (i) Secara objektif mengevaluasi kinerja sendiri, dan (j) Mengembangkan diri secara mandiri dan berkelanjutan.

3. Kompetensi sosial merupakan kemampuan guru sebagai bagian dari masyarakat, sekurang-kurangnya meliputi : (a)Berkomunikasi lisan, tulisan, dan/atau isyarat, (b) Menggunakan teknologi komunikasi dan informasi secara fungsional, (c) Bergaul secara efektif dengan peserta didik, sesama pendidik, tenaga kependidikan, pimpinan satuan pendidikan, orang tua/wali peserta didik, (d) Bergaul secara santun dengan masyarakat sekitar dengan mengindahkan norma serta system nilai yang berlaku, dan (e) Menerapkan prinsip-prinsip persaudaraan dan semangat kebersamaan.

4. Kompetensi professional merupakan kemampuan guru dalam menguasai pengetahuan bidang ilmu, teknologi, dan/atau seni yang sekurang-kurang meliputi penguasaan : (a) Materi pelajaran secara luas dan mendalam sesuai standar isi program satuan pendidikan, mata pelajaran, dan/atau kelompokmata pelajaran yang diampunya. (b) konsep-konsep dan metode disiplin keilmuan, teknologi, atau seni yang relevan yang secara konseptual menaungi atau koheren dengan program satuan pendidikan, mata pelajaran, dan/atau kelompok mata pelajaran yang diampu.

Keempat kompetensi tersebut di atas bersifat holistik dan integrative dalam kinerja guru. Oleh karena itu, secara utuh sosok kompetensi guru meliputi :

1. Pengenalan peserta didik secara mendalam;

2. Penguasaan bidang studi baik disiplin ilmu (diciplinary content) maupun bahan ajar dalam kurikulums ekolah (pedagogical content);

3. Penyelenggaraan pembelajaran yang mendidik yang meliputi perencanaan dan pelaksanaan pembelajaran, evaluasi proses dan hasil belajar, serta 
tindaklanjut untuk perbaikan dan pengayaan; dan

4. Pengembangan kepribadian dan profesionalitas secara berkelanjutan.

\section{Sertifikasi Dosen}

Berdasarkan Undang-undang No. 14 tahun 2005 tentang guru dan dosen pasal 1 ayat 11 dan 12 , Sertifikasi adalah proses pemberian sertifikat pendidik untuk guru dan dosen. Sedangkan sertifikat pendidik adalah bukti formal sebagai pengakuan yang diberikan kepada guru dan dosen sebagai tenaga profesional. Untuk mendapatkan sertifikat pendidik, maka pendidik baik dosen maupun guru harus ikut serta dalam proses sertifikasi dan harus memenuhi beberapa syarat berikut : 1. Memiliki kualifikasi akademik sekurang-kurangnya S2/setara dari Program Studi Pasca Sarjana yang terakreditasi;

2. Dosen tetap di perguruan tinggi negeri atau dosen DPK di perguruan tinggi yang diselenggarakan oleh masyarakat atau dosen tetap yayasan di perguruan tinggi yang diselenggarakan oleh masyarakat yang telah mendapatkan inpassing dari pejabat berwenang yang diberi kuasa oleh Mendiknas (pasal 4 Peraturan Menteri Pendidikan Nasional Nomor 20 tahun 2008);

3. Telah memiliki masa kerja sekurangkurangnya dua tahun di perguruan tinggi di mana ia bekerja sebagai dosen tetap;

4. Memiliki jabatan akademik sekurangkurangnya Asisten Ahli;

5. Melaksanakan Tridharma perguruan tinggi dengan beban kerja paling sedikit sepadan dengan 12 (dua belas) sks pada setiap semester di perguruan tinggi di mana ia bekerja sebagai dosen tetap. Tugas tambahan dosen sebagai unsur pimpinan di lingkungan perguruan tinggi diperhitungkan sksnya sesuai aturan yang berlaku;

6. Dosen yang belum memiliki kualifikasi akademik magister (S2)/ setara dapat mengikuti sertifikasi apabila: Mencapai usia 60 tahun dan mempunyai pengalaman masa kerja 30 tahun sebagai dosen, atau mempunyai jabatan akademik Lektor Kepala dengan golongan IV/c (Dosen PNS Dpk) Memiliki kriteria butir 1 dan 5 diatas

7. PTS pengusul serdos harus memperhatikan rasio dosen:mahasiswa untuk bidang IPA 1:20 (toleransi s/d 1:30) dan bidang IPS 1:30 (toleransi s/d 1:45).

\section{Kualifikasi Akademik}

Kualifikasi akademik adalah ijazah jenjang pendidikan akademik yang harus dimiliki oleh guru atau dosen sesuai dengan jenis, jenjang dan satuan pendidikan formal di tempat penugas. Berdasarkan undang-undang Guru dan dosen yaitu Undang-undang No.14 tahun 2005 pada pasal 45 berisi tentang Dosen wajib memiliki kualifikasi akademik, kornpetensi, sertifikat pendidik, sehat jasmani dan rohani, dan memenuhi kualifikasi lain yang dipersyaratkan satuan pendidikan tinggi tempat bertugas, serta memiliki kemampuan untuk mewujudkan tujuan pendidikan nasional.

Dari pasal 45 dijelaskan lebih rinci apa saja yang menjadi kualifikasi akademik dosen, hal ini dijelaskan secara gamblang pada undang-undang guru dan dosen pada pasal selanjutnya yaitu pasal 
46 ayat 1 sampai dengan 3 yaitu , dosen memiliki kualifikasi akademik minimum:

1. Melalui pendidikan tinggi program pascasarjana yang terakreditasi sesuai dengan bidang keahlian

2. Lulusan program magister untuk program diploma atau program sarjana; dan

3. Lulusan program doktor untuk program pascasarjana.

4. Setiap orang yang memiliki prestasi luar biasa dapat diangkat menjadi dosen

Dosen yang tidak memenuhi kualifikasi akademik kompetensi dan sertifikasi pendidik sebagaimana dimaksud dalam pasal 2 pada PP No. 37 Tahun 2009 maupun UU Guru dan dosen pasal 45 dalam jarak waktu 10 (sepuluh) tahun sejak berlaku UU No. 14 tahun 2005 tentang Guru dan Dosen dan yang bersangkutan telah diberi kesempatan untuk memenuhinya, dikenai sanksi oleh Pemerintah (maksudnya untuk dosen PTN), penyelenggara pendidikan tinggi atau satuan pendidikan tinggi yang diselenggarakan masyarakat ( maksudnya untuk dosen PTS) berupa:

1. Dialih tugaskan pada pekerjaan tenaga kependidikan yang tidak mempersyaratkan kualifikasi dosen.

2. Diberhentikan tunjangan fungsional atau subsidi tunjangan fungsional dan tunjangan khusus; atau

3. Diberhentikan dari jabatan sebagai dosen

\section{Pengalaman Mengajar}

Pengalaman mengajar merupakan salah satu faktor penting dalam melaksanakan kegiatan belajar dan mengajar. Pengalam mengajar dosen menjadi salah satu faktor yang menentukan hasil belajar dari mahasiswa. Pengalaman mengajar dosen merupakan kegiatan proses mengajar yang pernah dijalani oleh dosen tersebut. Menurut Undang-Undang nomor 14 tahun 2005 pada pasal 47 , pengalaman mengajar yang harus dimiliki minimal 2 (dua) tahun yang juga menjadi syarat untuk melakukan sertifikasi pendidik.

\section{Motivasi Dosen}

Menurut kamus besar bahasa indonesia, motivasi adalah dorongan yang timbul dalam diri seseorang secara sadar atau tidak sadar untuk melakukan tindakan dan tujuan tertentu.

Berdasarkan pengertian diatas maka dapat disimpulkan, motivasi adalah dorongan dari dalam diri karena adanya hasrat untuk mencapai cita-cita dan harapan. Karena motivasi ini, kompetensi akan meningkat dikarenakan adanya dorongan untuk menjadi tenaga yang berkompeten pada bidangnya

\section{METODE PENELITIAN}

Penelitian ini dilakukan pada Politeknik LP3I Medan. Politeknik LP3I yang berada di medan memiliki tiga cabang yang menjadi tempat penelitian ini yaitu :

1. Politeknik LP3I yang berada di Jl. Amaliun No.37, Kota Matsum IV, Medan Area, Kota Medan, Sumatera Utara 20215

2. Politeknik LP3I Medan Baru yang berada di Jl. Sei Serayu No.48D, Babura Sunggal, Medan Sunggal, Kota Medan, Sumatera Utara 20153. 
3. Politeknik LP3I Marelan Jl. Platina Raya No.8 ABC, Titi Papan, Medan Marelan, Kota Medan, Sumatera Utara 20243

Analisis data yang digunakan pada penelitian ini adalah deskriptif kuantitatif dengan membagi kuesioner untuk menganalisa faktor yang mempengaruhi kompetensi dosen. Data yang digunakan dalam penelitian ini adalah data primer yang bersumber dari hasil kuesioner dan data sekunder yang bersumber dari artikel, buku , jurnal , dan lain-lain. Metode pengumpulan data yang digunakan dalam penelitian ini adalah metode studi pustaka yang merupakan metode pengumpulan data yang dilakukan dalam penilitian ini untuk mecari sumber, bahan, penilitian terdahulu dan referensi lainnya . Dan juga metode studi lapangan yang menggnkan dua cara mengumpulkan data yaitu, angket (Questionnaire) yaitu suatu teknik atau cara pengumpulan data secara tidak langsung, metode pengumpulan data yang dilakukan dengan cara memberikan pertanyaan atau pernyataan untuk dijawab oleh responden dan dokumentasi merupakan teknik yang ditujukan untuk memperoleh data langsung dari tempat penelitian, meliputi buku, peraturan, laporan kegiatan, dan lain-lain.

Pengujian ini dilakukan untuk pengujian awal terhadap kelayakan data untuk diolah lebih lanjut sebagai dasar pengambilan keputusan atas hasil

\section{Statistik Deskriptif}

hipotesis. Pengujian ini dimulai dengan statistic deskriptif kemudian uji kelayakan kuesioner yaitu uji normalitas, uji validitas dan reabilitas data. Sedangkan uji hipotesis menggunakan analisis $\mathrm{t}$ parsial dan uji F simultan.

\section{HASIL PENELITIAN}

Untuk memperoleh data dalam menganalisa sejauh mana faktor-faktor yang diteliti mempengaruhi kompetensi dosen, maka disebarkan kuesioner kepada 45 dosen yang mengajar di Politeknik LP3I Medan. Penyebaran kuesioner dilakukan mulai tanggal 12 Februari-5 Maret 2018. Adapun kuesioner yang disebarkan sebanyak 45 eksemplar dan kuesioner yang kembali sebanyak 32 kuesioner (71\%), dari 32 kuesioner yang disebar 5 diantaranya dikembalikan dalam keadaan cacat. Pengolaan data dalam penelitian ini menggunakan SPSS 22.0 for Windows dan berikut ini adalah tabel penyebaran kuesioner :

Tabel 1. Data penyebaran Kuesioner

\begin{tabular}{|l|l|l|}
\hline Keterangan & Frekuensi & Presentase \\
\hline $\begin{array}{l}\text { Kuesioner yang } \\
\text { disebar }\end{array}$ & 45 & $100 \%$ \\
\hline $\begin{array}{l}\text { Kuesioner } \\
\text { Kembali }\end{array}$ & 32 & $71 \%$ \\
\hline $\begin{array}{l}\text { Kuesioner tidak } \\
\text { kembali }\end{array}$ & 12 & $27 \%$ \\
\hline $\begin{array}{l}\text { Kuesioner yang } \\
\text { di tolak }\end{array}$ & 1 & $2 \%$ \\
\hline
\end{tabular}

Sumber : Data Kuesioner 
Tabel 2. Statistik Deskriptif

Descriptive Statistics

\begin{tabular}{|l|l|l|l|l|l|}
\hline & $\mathrm{N}$ & $\begin{array}{l}\text { Minimu } \\
\mathrm{m}\end{array}$ & $\begin{array}{l}\text { Maximu } \\
\mathrm{m}\end{array}$ & Mean & $\begin{array}{l}\text { Std. } \\
\text { Deviation }\end{array}$ \\
\hline $\begin{array}{l}\text { Kualifikasi } \\
\text { Akademik }\end{array}$ & 32 & 1,00 & 2,00 & 1,7187 &, 45680 \\
$\begin{array}{l}\text { Pengalaman } \\
\text { Mengajar }\end{array}$ & 32 &, 00 & 20,00 & 7,5000 & 5,03696 \\
Motivasi Mengajar & 32 & 3,00 & 75,00 & 60,0000 & 14,93642 \\
Kompetensi Dosen & 32 &, 00 & 325,00 & 277,718 & 67,98113 \\
Valid N (listwise) & 32 & & & 8 & \\
\hline
\end{tabular}

Sumber : Output SPSS, Data diolah sendiri (2018)

Berdasarkan hasil output SPSS diatas nilai minimum dari variabel Kompetensi Dosen $(\mathrm{Y})$ dan Pengalaman Mengajar $\left(\mathrm{X}_{2}\right)$ adalah 0 , variabel Kualifikasi Akademik $\left(\mathrm{X}_{1}\right)$ adalah 1, variabel Motivasi Mengajar $\left(\mathrm{X}_{3}\right)$ adalah 3. Nilai maximum dari variabel Kompetensi Dosen (Y) adalah 325 , variabel Kualifikasi Akademik $\left(\mathrm{X}_{1}\right)$ adalah 2, Pengalaman Mengajar $\left(\mathrm{X}_{2}\right)$ adalah 20 dan variabel Motivasi Mengajar $\left(\mathrm{X}_{3}\right)$ adalah 75 . Nilai mean dari variabel Kompetensi Dosen (Y) adalah 277,718 , variabel Kualifikasi Akademik $\quad\left(\mathrm{X}_{1}\right) \quad$ adalah 1,7187 , Pengalaman Mengajar $\left(\mathrm{X}_{2}\right)$ adalah 7,50 dan variabel Motivasi Mengajar $\left(\mathrm{X}_{3}\right)$ adalah 60. Nilai standart deviasi dari variabel Kompetensi Dosen (Y) adalah 67,891, variabel Kualifikasi Akademik $\left(\mathrm{X}_{1}\right)$ adalah 0,456, Pengalaman Mengajar $\left(\mathrm{X}_{2}\right)$ adalah 5,036 dan variabel Motivasi Mengajar $\left(\mathrm{X}_{3}\right)$ adalah 14,396.

\section{Uji Asumsi Klasik \\ Analisis Uji Normalitas}

Uji normalitas dilakukan dengan menggunakan SPSS 22.0 for Windows dalam mempermudah pengujian data.

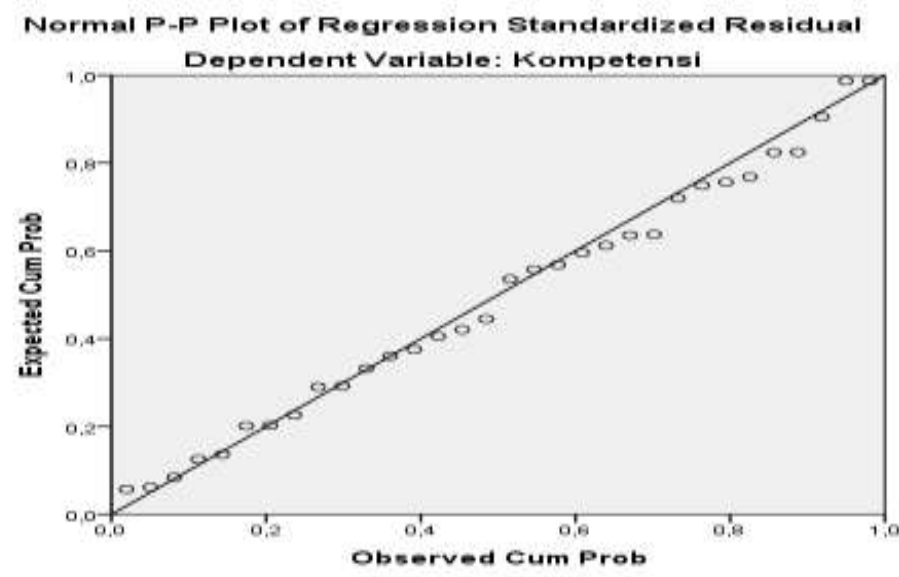

Gambar 1. Diagram Uji Normalitas

Sumber : Output SPSS, Data diolah sendiri (2018)

Pada grafik normal plot diatas dapat disekitar garis diagonal dan tersebar tidak dilihat bahwa titik-titik menyebar berjauhan dari garis diagonal, ini dapat 
disimpulkan bahwa data yang digunakan dalam penelitian ini berdistribusi normal.Untuk melengkapi dan menghindari kesalahan visual , maka perlu didampingi dengan uji statistik. Selain menggunakan grafik normal plot,

Tabel 3. Hasil Uji K-S

One-Sample Kolmogorov-Smirnov Test

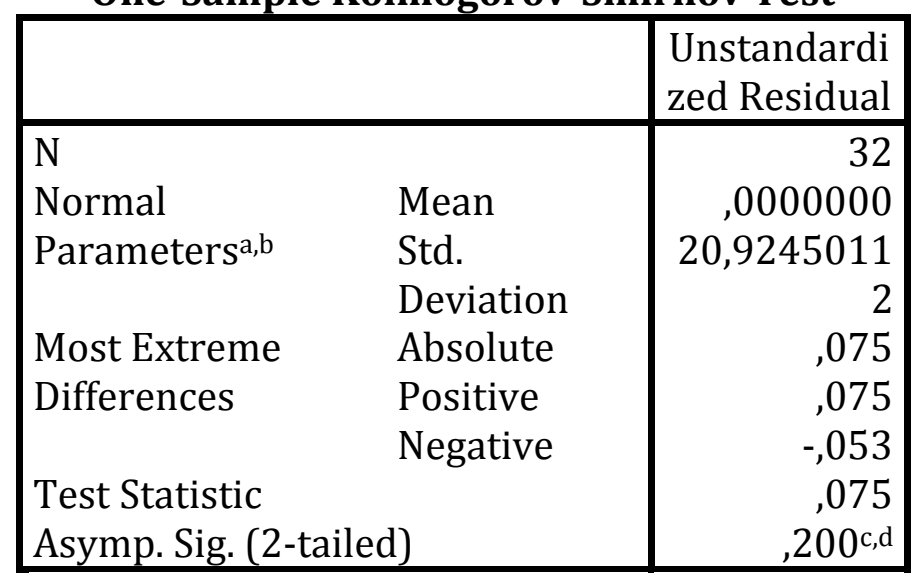
a. Test distribution is Normal.
b. Calculated from data.
c. Lilliefors Significance Correction.
d. This is a lower bound of the true significance.
Sumber : Output SPSS, Data diolah sendiri (2018)

Hasil uji normalitas dengan menggunakan Non-Parametik Kolmogorov smirnov menunjukan nilai Signifikansi sebesar 0,200. Berdasarkan hipotesis dan kriteria uji normalitas data, hasil perhitungan diatas lebih besar dari 0,05 sehingga $\mathrm{H}_{0}$ diterima yang berarti data berdistribusi normal.

\section{Analisis Uji Validitas}

Terdapat 80 butir pertanyaan dalam kuesioner yang disebar, dimana ada satu item yang dinyatakan tidak valid karena tidak memenuhi syarat $r_{\text {hitung }}>r_{\text {tabel }}$ dimana nilai $r_{\text {tabel }}$ sebesar 0,2869.

\section{Analisis Uji Reabilitas}

Suatu kuesioner dikatakan reliabel atau handal jika jawaban seseorang terhadap pernyataan adalah stabil dari waktu ke waktu. Berikut ini merupakan tabel hasi uji realibilitas menggunakan SPSS 20.0 for Windows : 
Tabel 5. Hasil Uji Reabilitas

Reliability Statistics

\begin{tabular}{|c|c|c|}
\hline $\begin{array}{c}\text { Cronbach's } \\
\text { Alpha }\end{array}$ & $\begin{array}{c}\text { Cronbach's } \\
\text { Alpha Based } \\
\text { on } \\
\text { Standardized } \\
\text { Items }\end{array}$ & $\begin{array}{c}\text { N of } \\
\text { Items }\end{array}$ \\
\hline, 958 &, 967 & 80 \\
\hline
\end{tabular}

Sumber : Output SPSS, Data diolah sendiri (2018)

Pada tabel diatas dapat dilihat nilai Cronbac's Alpha sebesar 0,967 atau 96,7\% lebih besar dari ketentuan nilai Cronbac's Alpha 0,70 yang berarti kuesioner dapat dikatakan reliabel atau handal.

\section{Uji Hipotesis}

Uji t Parsial
Dasar pengambilan keputusan dalam uji parsial yang berdasarkan hasil output SPSS 20.0 for windows yaitu , Jika nilai signifikan > 0,05 maka variabel tidak berpengaruh secara signifikan terhadap variabel terikat begitu juga dengan sebaliknya. Berikut ini merupakan tabel uji t parsial :

Tabel 6. Uji t Parsial

Coefficients $^{\mathbf{a}}$

\begin{tabular}{|c|c|c|c|c|c|}
\hline \multirow[b]{2}{*}{ Model } & \multicolumn{2}{|c|}{$\begin{array}{c}\text { Unstandardized } \\
\text { Coefficients }\end{array}$} & \multirow{2}{*}{$\begin{array}{c}\text { Standardiz } \\
\text { ed } \\
\text { Coefficient } \\
\text { s } \\
\\
\text { Beta }\end{array}$} & \multirow[b]{2}{*}{$\mathrm{t}$} & \multirow[b]{2}{*}{ Sig. } \\
\hline & B & $\begin{array}{l}\text { Std. } \\
\text { Error }\end{array}$ & & & \\
\hline 1 (Constant) & $\begin{array}{r}17,35 \\
1\end{array}$ & 25,480 & & 681 &, 501 \\
\hline Kualifikasi Akademik & $-3,263$ & 9,218 &,- 022 &,- 354 & ,726 \\
\hline $\begin{array}{l}\text { Pengalaman } \\
\text { Mengajar }\end{array}$ & ,329 & ,870 & ,024 & 378 & ,708 \\
\hline Motivasi Mengajar & 4,392 & ,287 & ,965 & 15,301 & ,000 \\
\hline
\end{tabular}

a. Dependent Variable: Kompetensi

Sumber : Output SPSS, Data diolah sendiri (2018)

Dari tabel output diatas dapat tidak berpengaruh secara signifikan disimpulkan bahwa Kualifikasi akademik terhadap Kompetensi Dosen (Y). Motivasi $\left(\mathrm{X}_{1}\right)$ dengan nilai signifikansi 0,726 lebih Mengajar $\left(\mathrm{X}_{3}\right)$ dengan nilai signifikansi besar dari 0,05 yang berarti tidak 0,00 lebih kecil dari 0,05 yang berarti berpengaruh secara signifikan terhadap berpengaruh secara signifikan terhadap Kompetensi Dosen (Y). Pengalaman Kompetensi Dosen (Y).

Mengajar $\left(\mathrm{X}_{2}\right)$ dengan nilai signifikansi 0,708 lebih besar dari 0,05 yang berarti Uji F Simultan 
Tabel 7. Uji F Simultan

\begin{tabular}{|ll|l|l|l|l|l|}
\hline \multicolumn{1}{|c|}{ ANOVAa $^{\text {Model }}$} & $\begin{array}{l}\text { Sum of } \\
\text { Squares }\end{array}$ & Df & $\begin{array}{l}\text { Mean } \\
\text { Square }\end{array}$ & F & Sig. \\
\hline 1 & Regression & 129691,592 & 3 & 43230,531 & 89,182 &, $000^{\mathrm{b}}$ \\
& Residual & 13572,877 & 28 & 484,746 & & \\
\multicolumn{1}{|l|}{ Total } & 143264,469 & 31 & & & \\
\hline
\end{tabular}

a. Dependent Variable: Kompetensi

b. Predictors: (Constant), Motivasi Mengajar, Kualifikasi Akademik, Pengalaman Mengajar

Sumber : Output SPSS, Data diolah sendiri (2018)

Pengambilan keputusan dalam uji silmultan ini adalah dengan melihat nilai signifikansi dari hasil output SPSS . Dari hasil Output diatas nilai signifikansi sebesar 0,00 dan nilai signifikansi lebih kecil dari nilai $\alpha=0,05$ yang berarti motivasi mengajar, latar belakang pendidikan ,dan pengalaman mengajar berpengaruh terhadap Kompetensi Dosen.

\section{Pengaruh Kualifikasi Akademik Terhadap Kompetensi Dosen}

Pada tebel 6 yang menunjukkan hasil uji t parsial yang dapat disimpulkan bahwa nilai signifikansi dari Kualifikasi Akademik sebesar 0,726 lebih besar dari 0,05 yang berarti tidak memiliki berpengaruh secara signifikan antara kualifikasi akademik terhadap kompetensi dosen.

Pada hasil uji parsial yang menunjukkan bahwa kualifikasi akademik tidak mempengaruhi kompetensi dosen bertolak belakang dengan penelitian yang dilakukan oleh Nurwati yang menyatakan bahwa latar belakang pendidikan memiliki pengaruh yang berarti terhadap kompetensi dosen dengan nilai signifikansi sebesar 0,020 yang lebih kecil dari 0,05. Dan memiliki nilai OR sebesar 4,88 setelah melewati uji analisis multivariat dengan regresi logistik.

Terdapat beberapa hal yang menyebabkan hasil dalam penelitian ini berbeda diantaranya masih cukup banyak dosen yang memiliki latar belakang pendidikan Strata-1 (S1). Selain itu, Politeknik LP3I merupakan lembaga pendidikan vokasi sehingga mengutamakan kemampuan serta keahlian ataupun prestasi yang pernah diperoleh dosen tersebut sesuai dengan bidang studi yang diampu.

\section{Pengaruh Pengalaman Mengajar Terhadap Kompetensi Dosen}

Pada tebel 6 yang menunjukkan hasil uji t (parsial) yang dapat disimpulkan bahwa nilai signifikansi dari Pengalaman Mengajar sebesar 0,708 lebih besar dari 0,05 yang berarti tidak memiliki pengaruh secara signifikan antara kualifikasi akademik terhadap kompetensi dosen.

Pada hasil uji parsial yang menunjukkan bahwa Pengalaman Mengajar tidak mempengaruhi Kompetensi Dosen, hasil ini sama dengan penelitian yang dilakukan oleh Nurwati yang menyatakan bahwa Pengalaman 21 
Mengajar tidak memiliki pengaruh yang berarti terhadap Kompetensi Dosen. Dalam penelitian sebelumnya menyatakan hanya latar belakang pendidikan yang memiliki hubungan yang berarti terhadap kompetensi dosen setelah dikontrol oleh variabel akta mengajar, beban mengajar, serta umur.

Hal ini disebabkan pengalaman mengajar tidak menjanjikan keberhasilan seorang dosen dalam mengajar tetapi menjadi salah satu faktor yang diterima menjadi seorang pengajar pada suatu lembaga ataupun instansi. Pada Politeknik LP3I masih banyak yang memiliki pengalaman mengajar dibawah 5 tahun atau sebesar $43,75 \%$ dari pada pengalaman 10 tahun keatas.

\section{Pengaruh Motivasi Mengajar Terhadap Kompetensi Dosen}

Pada tebel 6 yang menunjukkan hasil uji t (parsial) yang dapat disimpulkan bahwa nilai signifikansi dari Pengalaman Mengajar sebesar 0,0 lebih kecil dari 0,05 yang berarti memiliki pengaruh secara signifikan antara kualifikasi akademik terhadap kompetensi dosen.

Pada hasil uji parsial yang menunjukkan bahwa Pengalaman Mengajar mempengaruhi Kompetensi Dosen, hasil ini berbeda dengan penelitian sebelumnya oleh Nurwati karena memiliki variabel bebas yang berbeda.

Perbedaan variabel bebas menjadikan perbedaan dalam hasil penelitian ini pada penelitian sebelumnya. Motivasi memberikan pengaruh terhadap kompetensi dosen, karena motivasi dosen dalam mengajar dapat meningkatkan semangat dalam mengajar serta kinerja dosen tersebut.

\section{Pengaruh Kualifikasi Akademik, Pengalaman Mengajar dan Motivasi Terhadap Kompetensi Dosen}

Pada tebel 7 yang menunjukkan hasil uji f simultan yang dapat disimpulkan bahwa nilai signifikansi dari Kualifikasi Akademik, Pengalaman Mengajar dan Motivasi Dosen sebesar 0,00 lebih kecil dari 0,05 yang berarti memiliki pengaruh secara signifikan antara variabel bebas Kualifikasi Akademik, Pengalaman Mengajar dan Motivasi Dosen terhadap Kompetensi Dosen.

Pada hasil uji F Simultan menunjukkan sedikit persamaan dengan penelitian sebelumnya yang dilakukan oleh Nurwati dimana hanya latar belakang pendidikan yang memiliki pengaruh dan hubungan bermakna terhadap kompetensi dosen sedangkan pengalaman mengajar dan motivasi tidak memiliki pengaruh dan hubungan bermakna dalam penelitian sebelumnya.

Kualifikasi akademik pada penelitian ini memiliki persamaan dengan penelitian yangm dilakukan oleh Nurwati, hal ini disebabkan lebih banyak dan dominan dosen yang memiliki pendidikan Strata-2 (S2) sebesar 71,87\% dari pada Strata-1 (S1).

Perbedaan dalam penelitian ini dengan penelitian sebelumnya dimana terdapat perbedaan variabel bebas yang tidak sama diantaranya motivasi dosen. Perbedaan lainnya yaitu pengalaman mengajar memiliki pengaruh terhadap kompetensi dosen secara simultan, dimana pengalaman mengajar dosen pada Politeknik LP3I sedikit sekali yang dibawah 2 tahun mengajar dan lebih banyak serta dominan dosen yang 
memiliki pengalaman mengajar diatas 2 tahun.

\section{KESIMPULAN}

Dengan hasil penelitian yang telah dipaparkan serta dijelaskan di bab sebelumnya, maka hasil penelitian ini dapat disimpulkan berdasarkan Uji $t$ Parsial yang dilakukan faktor mempengaruh kompetensi dosen hanya Motivasi Dosen $\left(\mathrm{X}_{3}\right)$ yang mempengaruhi Kompetensi Dosen (Y) dengan memiliki nilai signifikansi sebesar 0,00 yang lebih kecil dari 0,05. Sedangkan faktor yang tidak berpengaruh adalah kualifikasi akademik dan pengalaman mengajar dengan nilai signifikansi sebesar 0,726 dan 0,708 yang lebih besar dari 0,05.

Dan berdasarkan Uji Simultan dengan menguji seluruh faktor secara bersama-sama, dapat disimpulkan faktor Kualifikasi Akademik ( $\left.\mathrm{X}_{1}\right)$, Pengalaman Mengajar $\left(X_{2}\right)$ serta Motivasi $\left(X_{3}\right)$ berpengaruh terhadap Kompetensi Dosen (Y) dengan memiliki nilai signifikansi sebesar 0,00 yang lebih kecil dari 0,05.

\section{DAFTAR PUSTAKA}

G, I. 2016 , Aplikasi Analisis Multivariate Dengan Program IBM SPSS 23, Cetakan kedelapan, Badan Penerbit Universitas Diponegoro, Semarang.

Kemdikbud. 2016, Kamus Besar Bahasa Indonesia, Diunduh di https://kbbi.kemdikbud.go.id/

Kopertis. 2016. Persyaratan Mengajukan Sertifikasi Dosen. Diunduh di https://kopertis3.or.id

Peraturan Pemerintah No. 37 tahun 2009 tentang dosen.

P. 2017. Kualitas Dosen Tentukan Mutu Perguruan Tinggi, Diunduh di https://news.okezone.com
S. (2014). Aplikasi Statistik Untuk Penelitian , Cetakan Pertama, Lentera Ilmu Cendekia, Tanggerang.

S, E. (2011). Analisis Faktor-Faktor yang Mempengaruhi Kompetensi Guru pada Sekolah Menengah Kejuruan Rintisan Sekolah Bertaraf Internasional di Kabupaten Indramayu. Tesis; Program Pasca Sarjana Ilmu Administrasi Universitas Indonesia (Dipublikasi).

S, V.W. (2014). Metodologi Penelitian , Cetakan Pertama, Pustaka baru press, Yogyakarta.

Undang-undang No. 14 tahun 2005 tentang guru dan dosen. 